This Section of Epidemiology and Psychiatric Sciences appears in each issue of the Journal and is dedicated to all forms of creative production born of an intimate and individual urge, often secretive, unbound from the conventional art system rules. Through short descriptions of the Outsider art work of prominent artists and new protagonists often hosted in community mental health services, this Section intends to investigate the latest developments of the contemporary art scene, where the distances between the edge and the centre are becoming more and more vague.

Carole Tansella, Section Editor

\title{
For the sake of beauty. Lyrical paintings by Giovanni Bosco
}

\section{Tansella}

Department of Time, Space, Image, Society, University of Verona, Verona, Italy

Key words: Giovanni Bosco, Outsider art, Italian Contemporary Art, Wall Paintings.
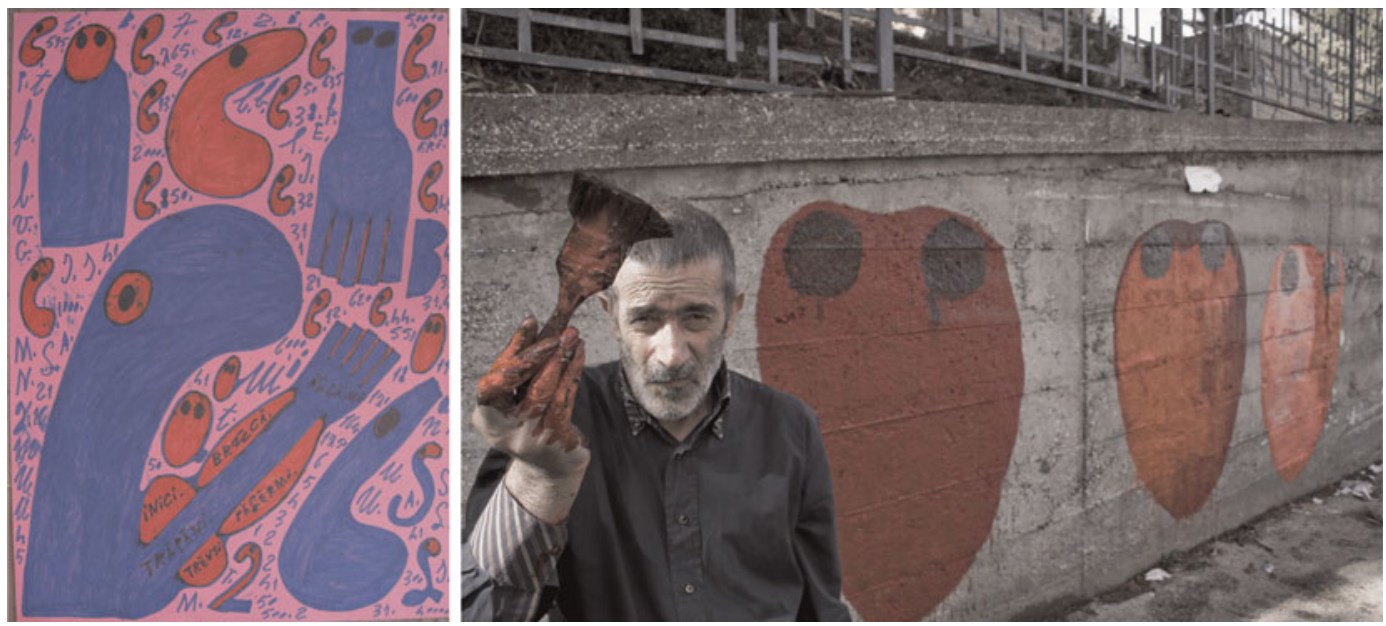

On the left: Giovanni Bosco: Untitled, Marker on pink cardboard, (2008), $70 \times 50 \mathrm{~cm}$, Photo by Teresa Maranzano. Courtesy Associazione Outsider Art Giovanni Bosco. On the right: Photo of the artist ahead of wall painted hearts in Salemi, Trapani, October 2008, Photo by Salvatore Bongiorno, ZEPstudio. Courtesy Associazione Outsider Art Giovanni Bosco.

As is often the case for outsider artists, recognition for the creative talent of Giovanni Bosco arrived late and

Address for correspondence: Dr Carole Tansella, Department of Time, Space, Image, Society, University of Verona, Via San Francesco 22, 37129 Verona, Italy. (E-mail: carole.tansella@gmail. com; carole.tansella@univr.it) unscheduled. His rise to fame did not come until the age of 60 .

Bosco was born in 1948 in Castellammare del Golfo, a small town in the province of Trapani, on the northwest coast of Sicily. He attended school up to the age of eight, and then followed in his father's footsteps in becoming a shepherd. Bosco was still only a child when he became fatherless. After the death of his 
father, Bosco led a marginalized existence, surviving on occasional work. One day, living as he did on the margins of society, he was accused of stealing two sheep and ended up in jail in Trapani.

In 1976, the news of the murders of his two brothers precipitated a psychotic episode after which Bosco was transferred from prison to a psychiatric hospital. Once discharged from the hospital, Bosco returned to his home town, where he continued to live a modest life (Di Stefano, 2009a).

Although there is no information on Bosco's creative activities during his time in hospital, we know with certainty however, that he was very active as an artist after he was released. Bosco worked both inside his house and on city streets. He used albums, cardstock and recycled materials such as pizza boxes and cabinet panels as canvas. He also would paint on the walls of old buildings in the old town centre. These would become the creative expression that would accompany him until the end of his days.

It would be Giovan Battista Di Liberti, a painter from Castellammare, who first noticed the extraordinary talent of Bosco. The first to support his work, Di Liberti would open up his workshop to Bosco and provide his 'irregular' peer the specific tools for the trade, without ever interfering with his original creative force (Di Stefano, 2009b).

In 2008, thanks to the eye of the photographer Boris Piot and insight of the French collective Animula Vagula, Bosco went from a state of anonymity to considerable fame. The interest of the Observatory Outsider Art at the University of Palermo and the prestigious Collection de l'Art Brut in Lausanne, which acquired some of his works, brought the artist success at the international level (Peiry, 2012). Meanwhile, ZEP, a filmmaker group in Castellammare, dedicated a documentary in his honour, and the Association Outsider Art Giovanni Bosco was to be founded to preserve his paintings and street art from the threats of sea winds and vandalism. Bosco passed away on April 1st 2009, too early to fully enjoy the admiration of his work.

Those who choose to embark on an idyllic journey to Castellammare, with the expectation of having the typical Sicilian postcard experience, will be disappointed. In the luminous silence, upon entering the city streets, the scent of lemon blooms and the clear sound of the water breaking against the rocks flash through the mind like distant memories. One feels like an alien catapulted in a cyber-primordial era, inhabited by robotic creatures and ancestral animals. From the building walls, vague anthropomorphic figures with bright colours, immobilized in clear profiles, seem to intensely observe the dazed tourist. Combining the human and mechanical elements, these innocent machines always possess a heart, in some cases more than one and have upper and lower limbs. Other times, the creatures are stripped of everything and are left with only an immensely beating heart; the source of life and intellect.

The viper is the other type of creature, depicted in an embryonic form, painted on the walls of Castellammare. The placid snake, similar to its ancestor who fled from the sea to find salvation and new life on the earth, escaped from Bosco's hands infused with colour and perfectly adapted to the urban landscape.

The cyber-primordial bestiary of Bosco's work and the expressive results of the Cobra group seem to be parallel solutions to an analogous problem. Bosco however rejected the frantic restlessness of informal developments; he is not satisfied with the synthesis between figurative and non-figurative art. Instead, Bosco fills up the pictorial speech, both on paper and on walls with words, numbers, dates and above all, song lyrics. Bosco was an avid fan of music and knew all the songs by the Neapolitan artist, Mario Merola. It is therefore no wonder that in his compositions, words and figures coexist harmoniously in an arrangement in which the pictorial representation becomes the limit of the element of sound. Bosco invites us to 'listen with our eyes' (Marin, 2001) and enjoy a pleasure that exceeds the traditional boundaries and unites the sensorial pleasure of sight and sound. One is forced to make an aesthetic leap in abandoning what is in front of them and chase the music, the voice and visions of Bosco's lyrical painting, thanks to a unique and paradoxical device, where you can 'see the voice.'

Bosco's mission was to bestow beauty to the community. As explained to his audience in a video interview, he produced his works ' for the sake of beauty' (ZEPstudio, 2009). Bosco's art derives from a generous gesture, although a gesture which leaves much ambiguity, far from common behaviour. There seems to be a perceived fine line between street art and vandalism, where the latter is viewed as a barbaric attack on civic society, especially when private property is concerned. The legitimacy of street art, which arises in the shadows of clandestinity in an attempt to regain possession of the city, is a matter of current debate.

Unfortunately, Bosco's works in Castellammare are in danger of disappearing (Di Stefano, 2013), like many street art that lack a strong patronage. Bosco's work is at risk of being painted over under the guise of restoration, as an attempt to redeem the city's 'ancient candor'.

The works of Giovanni Bosco are preserved in Italy by the Association Outsider Art Giovanni Bosco, 
Castellammare del Golfo and the Orestiadi Foundation, Museo delle Trame Mediterranee, Gibellina; in Switzerland, by the Collection de l'Art Brut in Lausanne; in France, by the ABCD Collection of Montreuil and in England, by the Museum of Everything, London.

Exhibits which Bosco participated in include: Giovanni Bosco, Atlante del Cuore, Museo delle Trame Mediterranee, Fondazione Orestiadi, Gibellina, 2009; Giovanni Bosco, Dottore di Tutto, Galerie Christian Berts, Paris, 2011; Banditi dell'Arte, Halle Saint Pierre, Paris, 2013.

\section{Financial support}

This research received no specific grant from any funding agency, commercial or not-for-profit sectors.

\section{Conflict of interest}

None.

\section{Supplementary materials and methods}

The supplementary materials referred to in this article can be found at http://dx.doi.org/10.1017/ S2045796013000371.

\section{References}

Di Stefano E (2009a). Anatomical Enigma. Eva Di Stefano Discovers the Late-Flowering Work of Artist Giovanni Bosco. Raw Vision, n.67. London.

Di Stefano E (2009b). Giovanni Bosco. Atlante del Cuore. Fondazione Orestiadi: Gibellina.

Di Stefano E (2013). Who Owns Outsider Art? Illegal Monuments: Ownership and Difficult Protection. Ethical Questions around Outsider Art, European Outsider Art Association, Museum Prinzhorn Collection: Heidelberg.

Marin L (2001). Della Rappresentazione. Meltemi: Roma. Peiry L (2012). Collection de l'Art Brut. Lausanne. Collection de l'Art Brut Lausanne Editions, Skira-Flammarion: Paris.

ZEPstudio (2009). Giovanni Bosco. Dottore di Tutto, Documentary 30. 